\title{
Vitamin D Status in Diabetic Ulcer in The Tropical Area
}

\author{
Raflis $^{1}$, Yanwirasti ${ }^{2}$, Hendro Sudjono Yuwono $^{3}$, Eva Decroli $^{4}$ \\ \{raflis_rustam@yahoo.co.id ${ }^{1}$ \} \\ Surgery Department of Medical Faculty, Universitas Andalas /Dr. M. Djamil Hospital Padang \\ Indonesia $^{1}$ \\ Department of Anatomic Medical Faculty Universitas Andalas Padang Indonesia ${ }^{2}$ \\ Surgery Department of Medical Faculty Padjajaran University/ Dr.Hasan Sadikin Hospital Bandung \\ Indonesia ${ }^{3}$ \\ Internal Medicine Department of Medical Faculty Universitas Andalas/Dr. M. Djamil Hospital \\ Padang Indonesia ${ }^{4}$
}

\begin{abstract}
Type 2 diabetes mellitus (T2DM) is a problem in health because it can cause a high disability and death worldwide. A metabolic disorder occurs which associated with pathophysiological changes in many organs in type 2 diabetes. Death is not caused by diabetes directly, but from its complications. Most complications are diabetic ulcers with a prevalence of $25 \%$. This paper was a cross-sectional study that highlight vitamin D status associated with diabetic ulcer. The study population was patients with diabetic ulcers who were treated (outpatient and inpatient) in dr. M. Djamil Padang Hospital and Ibnu Sina Yarsi Padang Hospital and others that met the inclusion and exclusion criteria. The number of samples was 36 people through interviews and medical record data. Our result shows data that vitamin D status was below the normal value in more than $50 \%$ of the diabetic ulcer. The results of the relationship between Vitamin D status and Wagner's classification of diabetic ulcer patients that there was no significant difference between vitamin $\mathrm{D}$ status $\mathrm{p}=1,000$. Vitamin D status can affect some medical condition. Vitamin D prevents and improves vascular disease, through improvement of anti-inflammatory and finally, it makes an endothelial dysfunction that contributes to being a diabetic ulcer.
\end{abstract}

Keywords: Diabetic Ulcer, Vitamin D, Vitamin D Status.

\section{Introduction}

Type 2 diabetes mellitus (T2DM) is a problem in health because it can cause a high disability and death worldwide[1]. The global prevalence of type 2 diabetes in adults over the age of 18 increases from $4.7 \%$ in 1980 to $8.5 \%$ in 2014, especially in developing and poor countries [1]. A metabolic disorder occurs which is associated with pathophysiological changes in many organs in type 2 diabetes. Death is not caused by diabetes directly, but from its complications. Most complications are diabetic ulcers with a prevalence of 25\% [1],[2].

Diabetic ulcers are preceded by peripheral artery disease (PAD), which is experienced by $20 \%$ of patients with DM, with various levels of clinical emergency. The process of diabetic ulcer begins with a state of chronic hyperglycemia which results in arterial endothelial dysfunction. Many factors and conditions can affect vascular endothelial inflammation, that 
currently, an important issue is vitamin D. Many studies have told about the role of vitamin D in diabetes and cardiovascular disease [3],[4].

So, this research aims to show the condition of vitamin D status in diabetic ulcer patients in tropical area.

\section{Materials and Methods}

It was cross-sectional designed research and the study population was patients with diabetic ulcers who were treated (outpatient and inpatient) in dr. M. Djamil Padang Hospital and Ibnu Sina Yarsi Padang Hospital and others, where the diagnosis of Diabetes Mellitus has been made by a specialist in internal medicine/endocrinologist. The sample of the study was part of the study population that met the inclusion and exclusion criteria.

The number of samples is 36 people through interviews and medical record data. Inclusion criteria are : age 40-65 years, HBA1c levels $>6.5 \%, \mathrm{ABI}>0.4$ to 1.2. Exclusion criteria a are a patient who was suffering from arterial complications: occlusion, bleeding; suffering from organ diseases that affect vitamin D metabolism, eg osteoporosis, hypothyroidism as a complication of diabetes or hypertension; There is a lesion or ulcer in the ankle, and infection, sepsis.

Vitamin D status is measured by $25(\mathrm{OH}) \mathrm{D}$ in serum and using electrochemiluminescence immunoassay analyzer (ECLIA) on the COBAS machine in the Biomedical laboratory of Medical Faculty Andalas University. The kit used is Diagnostics Biochem Canada (DBC). Serum levels of $25(\mathrm{OH}) \mathrm{D}$ are classified into 3 groups: normal if the concentration is $>30-32$ $\mathrm{ng} / \mathrm{mL}(75-80 \mathrm{nM})$. Concentrations below $20 \mathrm{ng} / \mathrm{mL}(50 \mathrm{nM})$ are called deficiencies, while between $20 \mathrm{ng} / \mathrm{mL}(50 \mathrm{nM})$ and 30-32 $\mathrm{ng} / \mathrm{mL}(75-80 \mathrm{nM})$ are insufficiency.

Clearing and editing process is carried out after collecting data. Then the data obtained were analyzed by computer systems and presented in the form of tables.

\section{Result}

\subsection{Patient Characteristics}

Table 1.Patient Characteristics

\begin{tabular}{ll}
\hline Variable & $\mathrm{f}(\%)$ \\
\hline Age (year) & $14(38.89)$ \\
$-\quad 40-<50$ & $15(41.67)$ \\
$-\quad 50-<60$ & $7(19.44)$ \\
$-\quad \geq 60$ & $17(47.22)$ \\
Sex & $19(52.78)$ \\
$-\quad$ Male & \\
Stage of Ulcer & \\
Classification of Wagner & \\
$-\quad$ Stadium 1 & $8(22.22)$ \\
$-\quad$ Stadium 2 & $11(30.55)$ \\
$-\quad$ Stadium 3 & $15(41.67)$ \\
\hline
\end{tabular}




\begin{tabular}{lll}
\hline - & Stadium 4 & $2(5.56)$ \\
First known DM (Age year) & \\
$-\quad 30-<40$ & $12(33.33)$ \\
$-\quad 40-<50$ & $15(41.67)$ \\
$-\quad 50-<60$ & $8(22.22)$ \\
$-\quad \geq 60$ & $1(2.78)$ \\
\hline
\end{tabular}

Based on Table 1. Most diabetic ulcers occur in the range 50-60 years old. The tendency for women was higher than for men $(52.78 \%$ vs $47.22 \%)$. Nearly $50 \%$ of patients suffered from advanced diabetic ulcers based on Wagner's classification (stages 3 and 4; $41.67 \%$ and 5.56\%). Commonly known as DM at the age of $>40$.

\subsection{Vitamin D Status in Diabetic Ulcer}

Table 2.Vitamin D Status in Diabetic Ulcer $(\mathrm{n}=36)$

\begin{tabular}{ll}
\hline Vitamin D status & $\mathrm{f}(\%)$ \\
\hline Normal $(>30)$ & $17(47.22)$ \\
Insufficiency $(20-29)$ & $12(33.33)$ \\
Defficiency $(0-19)$ & $7(19.55)$ \\
\hline
\end{tabular}

The vitamin D status was below the normal value in more than $50 \%$ of diabetic ulcer patients shown in Table. 2

\subsection{Relationship between Age and Vitamin D Status}

Table 3. The relationship between Age and Vitamin D Status

\begin{tabular}{llllll}
\hline \multirow{2}{*}{ Age } & \multicolumn{4}{c}{ Vitamin D } & \\
\cline { 2 - 5 } & & \multirow{2}{*}{ Normal } & \multicolumn{2}{l}{$\begin{array}{l}\text { Insufficiency } \\
\text { deficiency }\end{array}$} & and \\
\cline { 2 - 5 } & $\mathrm{F}$ & $\%$ & $\mathrm{~F}$ & $\%$ & \\
\hline $40-50$ years & 9 & 64.30 & 5 & 35.70 & 0.021 \\
$50-60$ years & 3 & 20.00 & 12 & 80.00 & \\
$>=60$ years & 5 & 71.40 & 2 & 28.60 & \\
\hline
\end{tabular}

Table 3 shows the results of the relationship between Vitamin D status and age in diabetic ulcer patients can be seen in that $80 \%$ of patients aged 50-60 years had a vitamin $\mathrm{D}$ value below normal values, this relationship was statistically significant with $\mathrm{p}=0.021$.

\subsection{Relationship Between Vitamin D Status and Wagner Classification}

Table 4. Relationship Between Vitamin D Status and Wagner Classification

\begin{tabular}{llllll}
\hline \multirow{2}{*}{$\begin{array}{l}\text { Wagner } \\
\text { Classification }\end{array}$} & \multicolumn{2}{l}{ Vitamin D } & \multicolumn{2}{l}{$\begin{array}{l}\text { Insufficiency } \\
\text { deficiency }\end{array}$} & and \\
\cline { 2 - 5 } & \multicolumn{2}{l}{ Normal } & Falue \\
\cline { 2 - 5 } & $\mathrm{F}$ & $\%$ & $\mathrm{~F}$ & $\%$ & \\
\hline Wagner 1 \& 2 & 9 & 47.40 & 10 & 52.60 & 1.000 \\
Wagner 3 \& 4 & 8 & 47.10 & 9 & 52.90 & \\
\hline
\end{tabular}


The results of the relationship between Vitamin D status and Wagner's classification of diabetic ulcer patients can be seen in Table 4. It was found that there was no significant difference between vitamin $\mathrm{D}$ status and age in diabetic ulcer patients with $\mathrm{p}=1.000$, but it is seen that more than $50 \%$ of patients with diabetic ulcers were in abnormal vitamin D status.

\subsection{Relationship Between Vitamin D Status and Body Mass Index}

Table 5. Relationship Between Vitamin D Status and Body Mass Index

\begin{tabular}{llllll}
\hline & \multicolumn{2}{l}{ Vitamin D } & & \multirow{2}{*}{$\begin{array}{l}\text { Insufficiency } \\
\text { BMI }\end{array}$} & \multicolumn{2}{l}{ Normal } & & p-value \\
& deficiency & & \\
\cline { 2 - 5 } & $\mathrm{F}$ & $\%$ & $\mathrm{~F}$ & $\%$ & 1.000 \\
\hline$<25.00$ & 12 & 48.00 & 13 & 52.00 & \\
$>=25.00$ & 5 & 45.50 & 6 & 54.50 & \\
\hline
\end{tabular}

The results of the relationship between Vitamin D status and BMI in diabetic ulcer patients can be seen in Table 5, it was found that there was no significant difference between vitamin D status and BMI in diabetic ulcer patients with $\mathrm{p}=1.000$.

\section{Discussion}

The majority (44.4\%) of diabetic foot sufferers aged 50-60 years, almost the same in both groups. Some literature in Indonesia about diabetic ulcers, among others, Padang gets an average age of 55.2 years, with a range of $40-59$ years $(65.8 \%)$, Manado gets $76.3 \%$ at the age of $>50$ years, Denpasar gets $46.9 \%$ at the age of $50-59$ years $(37.5+9.4)$ [5],[6],[7]. Most patients in age $>50$ years in other countries, India gest an average age of 58 years, another study showed an average age of 61 years and mostly occurs in the range of age 45-60 years[8],[9],[10]. Research by Zhang found an average age of $61.7 \pm 3.7$ years [11].

Research by Kahuripan found the result of diabetic ulcer patients is found in Lampung almost young, which is $50 \%$ at the age of 30-50 years. Data published by the Inter-Society Consensus for the Management of Peripheral Arterial Disease (TASC II), indicate that there is an increased incidence and prevalence of diabetic ulcer in accordance with increasing age, which is $3 \%$ in patients with diabetes over the age of 40 years, and $6 \%$ in over 60 years old [13].

The sex distribution between men and women had almost in the same ratio. Some studies have shown that the prevalence of the peripheral disease is more in men than women, $70 \%$, $55.3 \%$, and 53.1\% [5],[6],[7]. Another study in India found men (59.7\%), another study found men $(4.5 \%, 95 \%$ CI: $3.7-5.2)$ compared to women $(3.5 \%, 95 \%$ CI: $2.8-4.2)$ and male $(66.66 \%)$ [8].[9],[10]. However, different results in the Lampung study were $34.7 \%$ male and $65.3 \%$ female [12].

Male gender is a predominant factor associated with the occurrence of ulcers, but not a single risk factor for developing ulcers. In one study also found incidence and prevalence in men 2.2 times higher than women, which was caused by higher physical activity in men which facilitated diabetic ulcers. In the study by Dwikayana, high prevalence in men may be caused by the presence of central obesity[7]. 
The rate of ulceration clinically shows wide variations, ranging from closed lesions, superficial to deep ulcerations, even gangrene, known as Wagner classification. This study showed that the majority of participants had a stage 3 Wagner classification ulcer clinical condition Decroli obtained the same results, namely patients generally came with grade 3 ulcers $(55 \%)$. Kristiani gets different results that in general come with Wagner grade 4 grade $(26.3 \%)$ followed by grade $1(23.7 \%)$, almost the same as the results of Dwikayana, that patients came with grade $1(37.5 \%)$ and IV (37.5\%) [6],[7]. Research by Saseedharan, most patients came with ulcers that had affected tendons and capsules (49.1\%), patients with ulcers that affected the muscles $(40.7 \%)$ and up to joints and bones $(10.2 \%)$ [5],[6],[7],[8].

The vitamin D status is below the normal value in more than $50 \%$ of diabetic ulcer patients shown in Table. 2 The results of the relationship between Vitamin D status and age in diabetic ulcer patients can be seen in Table 3 . That $80 \%$ of patients aged 50-60 years had a vitamin D value below normal values, this relationship was statistically significant with $p=0.021$.

In the study by Zubair found that there was a significant relationship between vitamin $D$ status with the incidence of Diabetic Foot Ulcer $(\mathrm{p}<0.005)$ patients with Diabetic Foot Ulcer had an average of $8.4 \mathrm{ng} / \mathrm{ml}$ vitamin D levels, in general patients with Wagner classification grade $2(58 \%)[14]$. The results of this study are consistent with other studies showing that vitamin D prevents and improves vascular disease, through improvement of anti-inflammatory indicators such as Nitric Oxide (NO). Normally, endothelial cells produce NO which provides a vasodilating effect and protects blood vessels from endogenous injury. In conditions of low NO levels, vasoconstriction will occur resulting in disruption of endothelial microcirculation. Endothelial dysfunction can be triggered by hyperglycemia in patients with type 2 diabetes due to active inflammatory cytokines and initiating the development of diabetic feet, accompanied by neuropathic conditions [11],[15].

A study by Nasri told that the association between vitamin D status with age, in line with this study by Linnebur, found that in patients in their eighties (70\%) were in a insufficiency of vitamin D. This suggests that elderly people need vitamin D supplementation in order to meet their daily needs, besides that there are also several factors affecting vitamin D status in these parents such as other diseases that follow and Body Mass Index (BMI) [16],[17].

There was no significant relationship between BMI and vitamin D status in the body, but it can be seen that the number of BMI patients $<25$ had more normal vitamin D levels than $\geq 25$. This result is consistent with the study by Bischoff that there is a negative association between vitamin D status and BMI. $21.5 \%$ of normal subjects and only $12.9 \%$ of obese subjects will have a normal vitamin D status. This may be explained by a study by Wortsman, that the presence of fat deposition in obese individuals can cause a decrease in vitamin D bioavailability through the skin and diet [18],[19].

\section{Conclusions}

Our finding the vitamin D status is below the normal value in more than $50 \%$ of diabetic ulcer patients. That vitamin D prevents and improves vascular disease, through improvement of anti-inflammatory and finally, it makes an endothelial dysfunction that contributes to being a diabetic ulcer.

\section{References}


[1] WHO. Global Report On Diabetes. Http://Www.Who.Int (2016)

[2] Boulton, Andrew J.M. The Diabetic Foot: Grand Overview, Epidemiology, And Pathogenesis. Diabetes Metab Res Rev;24(Suppl 1):S3-6 (2008)

[3] Mathieu, C. And Adorini, L. The Coming Of Age Of 1, 25-Dihydroxyvitamin D 3 Analogs As Immunomodulatory Agents.Trends In Molecular Medicine, 8(4), Pp. 174-179.( 2002)

[4] Spina, C.S., Tangpricha, V., Uskokovic, M., Adorinic, L., Maehr, H. And Holick, M.F.Vitamin D And Cancer.Anticancer Res, 26(4a), Pp. 2515-2524 (2006)

[5] Decroli E, Karimi J, Manas S, Syahbuddin S. Profil Ulkus Diabetik pada Penderita Rawat Inap di Bagian Penyakit Dalam RSUP Dr. M. Djamil Padang, Majalah Kedokteran Indonesia. vol.58, no. 1, pp (2008)

[6] Kristiani AL, Sumangkut RM, Limpeleh HP. Hubungan Ankle Brachial Index Dengan Keparahan Ulkus Pada Penderita Kaki Diabetik. Universitas Sam Ratulangi, Manado (2015)

[7] Dwikayana M, Subawa AAN, Yasa WPS.Gambaran HbA1c Pasien Diabetes Mellitus Tipe 2 Dengan Komplikasi Ulkus Kaki Diabetik Di Poliklinik Penyakit Dalam RSUP Sanglah Denpasar Periode April-September 2014, E-Jurnal Medika. vol.5. no. 7 (2016)

[8] Saseedharan S, Sahu M, Chaddha R et al. Epidemiology Of Diabetic Foot Infections In Reference Tertiery Hospital In India, Braz J Microbiol. vol.49. pp 401-6 (2018)

[9] Jyothylekshmy V, Menon AS, Abraham S. Epidemiology of Diabetic Foot Complications in A Podiatry Clinic of A Tertiary Hospital in South India, Indian J Health Sci Biomed Res. vol.8. pp (2018)

[10] Chandrashekar S, Muralidhar S . A Study On The Prevalence Of Risk Factors And Presence Of Diabetic Foot Ulcers In T2DM Patients In K.R. Hospital, Mysuru, ISJ. vol.4. no. 9. pp 2983-6 (2017)

[11] Zhang P, Lu J, Jing Y, Tang S, Zhu D \& Bi Y. Global Epidemiology of Diabetic-Foot Ulceration : A Systematic Review And Meta-Analysis. Ann Med, vol. 49. no. 2. pp 106-16 (2017)

[12] Kahuripan A, Andrajati R, Syafridani T. Analisis Pemberian Antibiotik Berdasarkan Hasil Uji Sensitivitas Terhadap Pencapaian Clinical Outcome Pasien Infeksi Ulkus Diabetik Di RSUD Dr. H. Abdul Moeloek Lampung. Majalah Ilmu Kefarmasian, vol. VI no.2 pp 75-87 (2009)

[13] Norgen L, Hiatt WE, Dormandy MR et al. Inter Society Concensus for the Management of Peripheral Arterial Disease (TASC II). JVS, vol 45. no. 1(2006)

[14] Zubair M, Malik A, Meerza D \& Ahmad J. 25-Hydroxyvitamin D (25(OH)D) Levels and Diabetic Foot Ulcer: Is there Any Relationship?. Diabetes \& Metabolic Syndrome : Clinical Research \& Review. vol. 7. pp 148-53 (2013)

[15] Zhang, C.2008. The Role Of Inflammatory Cytokines In Endothelial Dysfunction. Basic Res Cardiol;103(5): 398-406

[16] Nasri H, Ardalan MR. Association of Serum Vitamin D Level with Age in Individual with Normal Renal Function. Journal of Nephropharmacology. vol. 1 no. 1(2012)

[17] Linnebur SA, Vondracek SF, Griend J et al. Prevalence of Vitamin D Insufficiency in Elderly Ambulatory Outpatients in Denver, Colorado. Amjopharm (2007)

[18] Bischof MG, Heinze G, Vierhapper H. Vitamin D Status and Its Relation to Age and Body Mass Index. Hormone Research, vol. 66 (2006)

[19] Wortsman J, Matsuoka LY, Chen TC, \& Holick MF 2000,'Decrease Bioavaibility of Vitamin D in Obesity', ASCN, vol. 72 